\title{
DINAMIKA JARINGAN INTELEKTUAL PESANTREN DI SULAWESI SELATAN
}

\author{
Oleh: Syamsuddin Arief*
}

\begin{abstract}
The dynamic of Muslim scholars' network between South Sulawesi (boarding school) and Haramains is believed to be a factor influencing the discourse of intellectual and Islamic tradition in South Sulawesi in the $20^{\text {th }}$ century. The "traditional Yellow Book" and intensive networking formed a new community consisting of the pilgrimages, Muslim scholars, boarding school students and the big and growing number of traders. The implication of the networking can be seen from the "halaqah" model originally started in Masjid al-Haram in Mecca and Masjid al-Nabawi in Madinah, then in houses called "Dar al-Arqam". In the context of South Sulawesi, As'adiyah Boarding school in Sengkang was considered to be the starting point of the development of boarding school in the $20^{\text {th }}$ century. This development was due to genealogic, ideological, and Yellow Book network, as well as social and political network.
\end{abstract}

KEYWORDS: Jaringan, genealogis, ideologis, kitab kuning

KEBERADAAN pesantren di Sulawesi Selatan pada umumnya berawal dari keinginan penguasa atau pemerintah supaya masyarakatnya dapat melaksanakan ibadah dengan baik dan benar. Dengan begitu, kehadiran kiai atau anre gurutta (A.G.) sangat diharapkan untuk menjadi pemimpin di pesantren tersebut.

Mula-mula musalla didirikan untuk menampung masyarakat sekitar yang datang beribadah dan mengaji. Kepiawaian dan kealiman kiai (dalam banyak kasus berupa karamah dan kehebatan ilmu beladirinya) menjadikannya semakin dikenal dan menarik simpati banyak orang. Subtansi pengajiannya pun semakin meningkat dan padat, dari hanya sekedar membaca syahadat, menjadi belajar Alquran, tafsir, hadis, bahasa Arab, hingga akhirnya sebagian besar kitab kuning (KK) yang dikuasai kiai. Animo para jamaah yang tinggi mendorong mereka "betah" untuk belajar bersama anre gurutta, dan karena itu tidak jarang di antara para santri ada

${ }^{*}$ Doktor lulusan Program Pascasarjana Universitas Islam Negeri Syarif Hidayatullah Jakarta, Jurusan Pendidikan Islam, ini adalah dosen Universitas Islam Negeri Alauddin Makassar dpk pada STAI DDI Barru. 
yang menawarkan diri menjadi khadam anre gurutta. Oleh karena itu, daya tampung musalla dan rumah anre gurutta menjadi sangat terbatas. Untuk menanggulangi hal tersebut, para santri bersama wali santri dan masyarakat sekitar secara bergotong royong mendirikan asrama (pondok) sebagai tempat tiggal mereka selama menuntut ilmu kepada anre gurutta. Sejak itu, pesantren mulai dikenal, ${ }^{1}$ dan sejak itu pula dimulailah proses terbentuknya jaringan intelektual secara alami dan berkesinambungan.

Terbentuknya jaringan intelektual (hubungan dan koneksi gurumurid) tidak dapat dipisahkan dari sistem pendidikan pesantren dan doktrin anre gurutta pada umumnya. Yang penting dari proses santrinisasi itu adalah penanaman perasaan kewajiban dan tanggung jawab mereka untuk melestarikan penyebarluasan pengetahuan tentang Islam kepada orang lain. Sehingga sepulang dari pesantren, mereka mempunyai tanggung jawab moral untuk mendirikan dan atau berafiliasi atau mendarmabaktikan dirinya dalam dunia pesantren yang telah ada.

Dari uraian tersebut, perlu ditegaskan bahwa hijrah li al-'ilm (safari dari suatu tempat ke tempat lain dalam rangka menuntut dan menyebarluaskan ilmu) merupakan ajaran Islam yang banyak mentradisi dalam

dunia pesantren. ${ }^{2}$ Faktor inilah yang tampaknya cukup signifikan dalam mempengaruhi dinamika jaringan intelektual pesantren. Oleh karena itu, dalam tradisi pesantren dikenal adanya istilah "santri keliling" atau "santri kelana". Artinya, seorang santri tidak hanya belajar di satu pesantren, tetapi ia berpindah-pindah dari satu pesantren ke pesantren lainnya dengan tujuan mengejar pengetahuan agama sesuai dengan spesialisasi keilmuan yang dimiliki anre gurutta.

\section{JARINGAN GENEALOGIS}

Jaringan genealogis terbentuk melalui hubungan darah atau kekerabatan antara anre gurutta ${ }^{3}$ yang satu dengan anre gurutta lainnya. Anre gurutta pada umumnya sangat jeli dalam memperhatikan dan memilih calon "menantu" dari murid-muridnya. Santri yang dinilai alim dan patuh biasanya menjadi calon pelanjut para anre gurutta. Dalam mengembangkan jaringan ini, sebagian besar anre gurutta mempunyai isteri lebih dari satu, dan karena itu, pada umumnya mereka mempunyai keturunan relatif banyak.

Penelusuran dan penelitian mengenai silsilah para kiai di Indonesia yang telah dirintis oleh Azyumardi Azra, setidaknya, telah memberi angin baru bagi lahirnya karya-karya biografi inlektual beberapa ulama di Indonesia. Dalam 12 tahun terakhir, mata kuliah "Islam di Indonesia: Sejarah Sosial-Intelektual" dan "Islam di Indonesia dalam Abad 19 dan 20: 
Kontinuitas dan Perubahan" 4 telah dimasukkan sebagai salah satu mata kuliah pada Program Pascasarjana UIN Syarif Hidayatulla Jakarta. Hal ini telah memberi momentum yang cukup baik bagi pengembangan wacana sosial intelektual

Dhofier menulis, sarana utama yang ditempuh para kiai dalam melestarikan dan mempertahankan tradisi pesantren adalah membangun sosialisasi dan kerjasama antara mereka dengan tiga cara, yaitu: a) mengembangkan tradisi bahwa keluarga yang terdekat harus menjadi colon kuat pengganti kepemimpinan pesantren; b) mengembangkan suatu jaringan perkawinan endagomous antara keluarga kiai; dan c) mengembangkan tradisi transmisi pengetahuan dan transmisi mata rantai intelektual antara sesama kiai dan keluarganya. ${ }^{5}$

Melalui pemahaman terhadap apa yang dikemukakan oleh Dhofier tersebut, maka dapat ditemukan bahwa banyak pesantren di Sulawesi Selatan yang tidak mampu berkembang bahkan mengalami kemunduran karena tidak memiliki anre gurutta (kiai), atau secara intelektual tidak menyiapkan generasi penerus. Oleh karena itu, seorang anre gurutta (kiai) menjadi krusial eksistensinya, tidak hanya karena posisinya sebagai "guru utama", tetapi langsung atau tidak langsung, anre gurutta (kiai) menjadi simbol, semangat, dan ruh dari eksistensi pesantren tersebut.

Ternyata pesantren yang maju di Sulawesi Selatan seperti As'adiyah, DDI, dan Darul Istiqamah, memperlihatkan bahwa suksesi kepemimpinan pesantren pada umumnya terjadi dalam lingkungan keluarga pendiri. Perlu dipahami bahwa kehadiran pesantren di Sulawesi berbeda dengan kehadiran pesantren di pulau Jawa. Di Sulawesi pada umumnya pemerintahlah yang memfasilitasi keberadaan pesantren kemudian didukung oleh para anre gurutta sebagai pimpinan pesantren. Sedang di Jawa, pesantren didirikan oleh para kiai dan merupakan milik pribadi kiai. Beberapa pesantren di Jawa dan Madura memperlihatkan bahwa suksesi kepemimpinan pesantren pada umumnya terjadi dalam lingkungan keluarga pendiri. Misalnya, Pesantren Tebuireng, Pesantren Sukorejo, dan Pesantren Tremas Pacitan masih menunjukkan bahwa periodisasi kepemimpinan pesantren tetap berperoses pada jalur "darah biru".

Hal di atas dapat dilihat, misalnya, pada contoh alur sebagai berikut: Pesantren Tebuireng periode I dipimpin oleh K.H. Hasyim Asy'ari (18991947); periode II dipimpin oleh K.H. Wahid Hasyim (1947-1950) atau putra kelima Hasyim dan Nafiqah; periode III dipimpin oleh K.H. Muhammad Abdul Karim Hasyim (1950-1951) atau putra ketujuh Hasyim dan Nafiqah; dan periode VI dipimpin oleh K.H. Yusuf Hasyim (1965-Sekarang) atau putra kesepuluh Hasyim dan Nafiqah. 
Dibandingkan di Sulawesi Selatan, para pimpinan pesantren itu dipilih dengan sistem musyawarah, misalnya: MAI Sengkang periode pertama (1930-1952) dipimpin oleh Anre Gurutta H. Muhammad As'ad; periode kedua (1953-1961) dipimpin oleh Anre Gurutta Daud Ismail; periode ketiga (1961-1986) dipimpin oleh Anre Gurutta H. M. Yunus Martan; periode keempat (1986-1988) dipimpin oleh Anre Gurutta Hamzah Badawi; dan periode kelima (1988-2000) dipimpin oleh Anre Gurutta Abdul Malik. Demikian seterusnya dinamika masa kepemimpinan pesantren di Sulawesi Selatan yang didasarkan atas keputusan musyawarah dan mufakat.

Bagi masyarakat pesantren, ilmu diniyah sebagai suatu yang suci, sakral dan tidak boleh spekulatif. Puncak dari pandangan ini adalah bahwa ilmu dianggap wahyu tersendiri atau, paling tidak, hadir sebagai penjelas wahyu. Dengan begitu, dipahami bahwa wahyu hanya "dimonopoli" oleh Nabi, maka ilmu juga diyakini hanya bisa dikuasai oleh ilmuan atau ulama. ${ }^{6}$ Pandangan ini tampaknya dipengaruhi oleh pandangan mereka terhadap hadis Nabi yang berbunyi al-'ulamā'u waratsat al-anbiyā'7 (ulama adalah pewaris para nabi). Dengan pandangan keilmuan yang demikian ketat dan tidak dinamis, pengajaran dan pendidikan yang berlangsung selalu merupakan pengulangan sebatas "kata-kata" ulama. ${ }^{8}$

Ada dua konsekuensi yang paling berkaitan dengan hal ini. Pertama, keseragaman atau homogenitas akan dengan mudah menjadi ciri yang sangat mencolok. Kalau saja terjadi perbedaan, maka perbedaan itu hampir bisa dipastikan hanya dalam pengungkapan saja. Kedua, kitab sebagai karya para ulama terdahulu yang memberikan keterangan langsung tentang kata-kata wahyu yang bersifat sentral, sementara kiai yang memberikan keterangan atas kitab ini hanyalah subordinat atau sekedar alat baginya (tidak berhak mengevaluasinya). ${ }^{9}$

Menarik untuk ditelusuri jaringan kitab gundul atau keilmuan Islam di Sulawesi Selatan, khususnya model Salafi, yang sampai saat ini pemahamannya masih tetap dipertahankan. Oleh karena itu, wacana keilmuan dan intelektual yang mewarnai dunia pesantren pada umumnya adalah wacana kitab kuning (KK) yang lazim disebut kitab gundul. Bagi kalangan pesanren, kitab gundul ini adalah referensi yang kandungannya tidak perlu dipertanyakan lagi. Kenyataan bahwa kitab kuning yang ditulis sejak lama dan terus dipakai dari masa ke masa menunjukkan bahwa kitab kuning telah teruji kemapanannya. Kitab kuning dipandang sebagai pemasok teori dan ajaran yang sudah sedemikian rupa dirumuskan oleh ulama-ulama yang bersandar pada Alquran dan hadis. ${ }^{10}$ 
Untuk mengetahui tradisi keilmuan di pesantren secara profesional dan objektif, maka klasifikasi kitab kuning berikut dipandang penting untuk disajikan.

\section{Tradisi Keilmuan}

\begin{tabular}{|c|c|c|}
\hline No. & Bidang Keilmuan & Nama Kitab yang Dipelajari \\
\hline 1. & Tafsir & $\begin{array}{l}\text { Tafsīr Jalālain, Tafsīr al-Maraghī, Tafsīr al- } \\
\text { Wādhīh, Shafwā al-Tasr, al-Asās fī al-Tafsīr, } \\
\text { Tafsīr Ibnu Katsīr, Mu'jizat al-Qur'an, al-Durār } \\
\text { al-Mantsūr }\end{array}$ \\
\hline 2. & Hadis & $\begin{array}{l}\text { Bulūgh al-Marām, Riyādh al-Shālihīn, Shahih al- } \\
\text { Bukhārī, Durrat al-Nāshihīn, Mukhtār al-Hadīts, } \\
\text { Jawāhir al-Bukhārī, Matn al-Arbā'in, Subul al- } \\
\text { Salām, Nuzhā al-Muttaqīn }\end{array}$ \\
\hline 3. & Tauhid/Akidah & $\begin{array}{l}\text { Tanwīr al-Qulūb, al-Husūn al-Hamidiyyah, al- } \\
\text { Jawāhir al-Kalamiyyah, Sullam al-Mantiq, Kifā- } \\
\text { yat al-Awām, Tauhid al-Khālik, Fath al- Qarīb }\end{array}$ \\
\hline 4. & Fikih & $\begin{array}{l}\text { Fath al-Mu'īn, Bidāyat Al-Mujtahid, Fath al- } \\
\text { Qarīb, Irsyād al-'Ibād, Tanwīr al-Qulūb, I'ānat } \\
\text { al-Thālibīn, al-Madzāhib al-Arba'ah, Fiqh al- } \\
\text { Sunnah, Minhāj al-'Ā'bidīn, Safinat al-Najā, } \\
\text { Manhāj al-Thullāb, Kifāyat al-Akhyār }\end{array}$ \\
\hline 5. & Akhlak & $\begin{array}{l}\text { Māuda al-Mu'min, Ta'līm al-Muta'allim, Akh- } \\
\text { lāq al-Banāt/Akhlāq al-Banīn, Hidāyat al-Sabab }\end{array}$ \\
\hline 6. & Sejarah & Sejarah DDI, Barasanji \\
\hline 7. & Tasawuf & $\begin{array}{l}\text { Syarah Hikam, Marāq al-'Ubūdiyyah, Sirāj al- } \\
\text { Thālibīn, Minhaj al-'Ā Abidīn, Kifāyat al-Thālibīn, } \\
\text { Ihyā' 'Ulūm al-Dīn }\end{array}$ \\
\hline 8. & Nahu/Sharaf & $\begin{array}{l}\text { Jurūmiyyah/Syarah Jurūmiyyah, Qawā'id al- } \\
\text { I'rāb, al-Nahwu al-Wādhih, al-Qawā'id al- } \\
\text { Lughat al-'Arabiyah, Alfiyah Ibnu Mālik, al- } \\
\text { Qawā'id al-Asāsiyyah }\end{array}$ \\
\hline 9. & Balāghah & Al-Balāghat al-Wādhihah \\
\hline 10. & Tajwid & Al-Imām Zarkasyi \\
\hline 11. & Al-Mantiq (logika) & Muhamad Nur Ibrahim \\
\hline 12. & Uhul Fikih & $\begin{array}{l}\text { Nail al-Ma'mul 'alā Nadmi Sullam al-Ushūl, al- } \\
\text { Sulam, Usul Fiqh Abdul Wahab Khallaf }\end{array}$ \\
\hline
\end{tabular}

Jaringan kitab kuning yang bersumber dari Pesantren As'adiyah hampir semuanya diajarkan secara seragam di berbagai pesantren di Sulawesi Selatan, meski tidak didahului dengan kesepakatan di antara para anre gurutta dalam menetapkan kurikulum. 
Para anre gurutta atau kiai yang hidup di akhir abad XIX dan paruh pertama abad XX memang pada umumnya sempat belajar di Tanah Suci dan ketika pulang ke tanah air mereka telah memiliki jalinan dan jaringan intelektual yang relatif erat. ${ }^{11}$ Dengan kata lain basis pembetuk jaringan anre gurutta relatif sangat dipengaruhi oleh epistemologi kitab kuning yang digunakan di berbagai pesanren.

Anre Gurutta H. Muhammad As'ad lahir di Makkah pada tahun 1907 dan belajar di Tanah Suci dengan berbagai guru sampai di Madrasah alFalāh Haramain. Ketika pulang ke tanah air tahun 1928 beliau telah memiliki jaringan intelektual atau kitab gundul yang siap diajarkan di nusantara, meskipun dengan sistem pembelajaran halaqah dan belum ada pembagian tingkat. Dalam perkembangan selanjutnya sistem pengajian kitab dibagi menurut tingkatan sekolah seperti yang dikembangkan oleh Darud Da'wah wal-Irsyad Abdurrahman Ambo Dalle (DDI-AD) Mangkoso Barru Sulawesi Selatan sebagai berikut.

Kitab Pengajian ${ }^{12}$

\begin{tabular}{|c|c|c|}
\hline \multicolumn{3}{|c|}{ TINGKATAN } \\
\hline Salafiyah & Tsanawiyah dan Aliyah & Ma'had 'Ālīy \\
\hline $\begin{array}{l}\text { Juz Amma \& } \\
\text { Terjemahnya }\end{array}$ & Fath al-Mu'in & Mau'izhat al-Mu'minīn \\
\hline Arba'īn Nawawiyah & Kifāyah al-Akhyār & $\begin{array}{l}\text { Al-Akhwāl al-Syakh- } \\
\text { shiyyah }\end{array}$ \\
\hline Jawāhir al-Kalāmiyah & $\begin{array}{l}\text { Irsyād al-‘'Ibād, Minhaj al- } \\
\text { Ābidīn }\end{array}$ & Hidāyat al-Mursyidīn \\
\hline Mabādi' al-Fiqhiyah & $\begin{array}{l}\text { Fath al-Qarīb, Hazīnat al- } \\
\text { Asrār }\end{array}$ & Rūh al-Dīn al-Islām \\
\hline Hilyat al-Syabāb & Tanwīr al-Qulūb & Khazīnat al-Asrār \\
\hline $\begin{array}{l}\text { Dakwah: Teori dan } \\
\text { Praktek }\end{array}$ & Al-Azkār li al-Nawawīy & Minhaj al-Thālibīn \\
\hline Seni Baca al-Qur'an & Al-Imām & Tanwīr al-Qulūb \\
\hline Barzanji/Sirah & Al-'Ibādah & Maraqy al-`Ubudiyah \\
\hline Riyādh al-Shālihīn & Kifayāt al-Akhyār & $\begin{array}{l}\text { Al-Khashāish al- } \\
\text { 'Ammah }\end{array}$ \\
\hline Kifayāt al-Akhyār & Fath al-Qarīb & \\
\hline Irsyād al-'Ibād & Irsyād al-‘Ibād & Tarbiyyat al-Aulād \\
\hline $\begin{array}{l}\text { Fath al-Qarīb, Tanwīr } \\
\text { al-Qulub }\end{array}$ & Riyādh al-Shālihīn & Fiqh al-Sirah \\
\hline Marāqib al-`Ubudiyah & Bidāyat al-Hidāyah & Al-Azkār li al-Nawawīy \\
\hline
\end{tabular}




\section{JARINGAN IDEOLOGIS}

Jaringan ini terbentuk karena adanya persamaan kepentingan dan ideologi, baik yang bersifat pemahaman keagamaan maupun ideologi politik. Meskipun tidak semua Anre Gurutta terlibat dalam dunia politik, sebagiannya secara tegas berafiliasi dalam partai politik tertentu.

Jaringan politik di Sulawesi Selatan dapat dilacak secara jelas pada pemilu 1977 dan pemilu di era multi partai, yakni pemilu 1999. Berdasarkan pengamatan di lapangan, beberapa pesantren dan kiainya terlibat langsung dalam proses politik, seperti kampanye pemilu dan lobilobi politik. Seperti pimpinan pesantren DDI Anre Gurutta Haji Abdurahman Ambo Dalle, pimpinan Pesantren DDI Al-Furqan Pare-pare A.G.H. Abduh Pabbaja, A.G.H. Wahab Zakariyah, dan H. Rahman Salika.

Demikian pula halnya di Jawa dan Madura, misalnya saja K.H. Alwy Muhammad (Jurkam Vokal PPP, pimpinan pesantren al-Taraqqi, Sampang Madura), K.H. Abdurrahman Wahid dan K.H. Said Aqiel Siraj sebagai pemrakarsa pendirian PKB, K.H. Sukron Makmun, pengasuh Pesantren Darul Rahman dan K.H. Hamdan Rasyid, pengasuh Pesantren alHamidiyah Depok, sebagai jurkam PNU (Partai Nahdatul Ulama), dan K.H. Hasyim, pemimpin pesantren Tebuireng yang turut mendukung berdirinya Partai Kebangkitan Umat (PKU). ${ }^{13}$

Sebagian pesantren lainnya bersikap "no politic in pesantren" dan sebagian lagi bersikap terbuka dan demokratis, dalam arti baik santri maupun kiai diberi kebebasan untuk menentukan pilihan dan afiliasinya. Nuansa kebebasan itu tampak misalnya pada Pesantren DDI Mangkoso, Pesantren DDI Pare-pare, Pesantren As'adiyah Sengkang Wajo, Pesantren Darul Istiqamah Maccopa Maros, Pesantren Al-Urwatu al-Wusqah Sidenreng Rappang.

Pada hakikatnya, perkembangan sebuah pesantren sangat bergantung pada kemampuan pribadi anre gurutta. Sosok anre gurutta, ${ }^{14}$ khususnya di Sulawesi Selatan, termasuk juga kiai di Jawa, Sumatera, Kalimantan, dan Madura, merupakan figur kunci bagi eksistensi pesantren (lembaga pendidikan). Ciri khas paling menonjol dalam jaringam pesantren adalah jaringan, silsilah, sanad intelektual. Ciri ini jelas menentukan tingkat kualitas dan keabsahan seorang ulama. ${ }^{15}$ Tradisi intelektual para ulama, termasuk di pesantren, agak berbeda dengan di kampus dan bahkan di lembaga pendidikan Islam lainnya. Misalnya, tradisi intelektual pesantren, mensyaratkan apa yang disebut: Pertama, "continous chain of knowledge" (silsilah keilmuan). Kedua, kepada siapa seseorang itu belajar (figure mainded). Kalau syarat pertama melahirkan 
jaminan kontinuitas dan keabsahan keilmuan, maka yang kedua melahirkan garansi figur otoritatif (otoritative figure). Oleh karena itu, dalam tradisi pesantren, orang pandai dalam ilmu agama tidak serta-merta disebut "kiai" atau "ulama" kalau silsilah keilmuannya tidak jelas sumbernya. ${ }^{16}$

Dari sini kemudian dijelaskan bagaimana posisi dan hubungan gurumurid menjadi bagian yang selalu harus ada dalam tradisi intelektual pesantren. Lebih lanjut lagi, tradisi intelektual pesantren mengajukan syarat-syarat orang disebut alim, ulama atau kiai. Pertama, orang tersebut memang belajar dan mempunyai guru, sebagaimana yang dikatakan oleh Ibn al-Qayyim al-Jauziy sebagai madārij al-sālikin, atau bi al-ta'allum menurut istilah Imam al-Ghazali dalam Ihyā' 'Ulūm al-Dìn. Selanjutnya, kedua, berilmu karena "ladunni", yaitu kepandaian langsung yang dianugerahkan oleh Allah kepada orang-orang terpilih. Al-Ghazali menyebutnya sebagai 'ilmu bi al-taqarrub sebagai ilmu yang diperoleh langsung karena kedekatan spiritual kepada Tuhan (spiritual impact). Meskipun demikian, sikap ini bagi orang lain mungkin bisa disebut "primordialisme pesantren".

Dari saling silang guru-murid dan terbentuknya relasi keilmuan menempatkan posisi Sengkang-Wajo sebagai pusat keilmuan abad ke 20, khususnya sampai pada pertengahan abad 20. Boleh jadi, "SengkangWajo" mulai awal abad ke 20 sampai 1970-an menjadi "al-Haramain"-nya Sulawesi Selatan sebelum beberapa pesantren lain berdiri. Jejak keilmuan Gurutta As'ad masih bisa dilihat dari penggunaan kitab kuning pada pesantren yang didirikan oleh muridnya. Hampir semuanya, tentu saja ada beberapa kitab kuning yang sudah ditambah dalam pengajian, kitab kuning yang dipakai dalam "mangaji tudang" (pengajian halaqah) masih dipertahankan seperti Riyādh al-Shālihīn, Tanwīr al-Qulūb, Tafsir Jalālain, Fath al-Mu'īn, Irsyād al-'Ibād, Syarh al-Hikam, Mau'idzat al-Mu'minīn, alMuhazzab dan sebagainya.

Berkembangnya pusat-pusat keilmuan dari Sengkang-Wajo ke beberapa tempat yakni Soppeng, Bone, Mangkoso, Pare-pare, Sidrap, Pinrang, dan Luwu, jelas menambah semarak dan dinamika keilmuan. Lahirnya beberapa pesantren baru selain As'adiyah Sengkang menjadikan bukti bahwa telah terjadi kontak keilmuan yang cukup intensif di kalangan santri. Munculnya figur Anre Gurutta Ambo Dalle (DDI) dan Marzuki Hasan (Darul Istiqamah) tidak sekedar menyambung "ajaran-ajaran" guru mereka, tetapi juga melakukan sintesis dan bukan tidak mungkin melakukan kritik internal.

Anre Gurutta As'ad tidak mengajarkan secara formal tarekat kepada murid-muridnya, tetapi juga tidak melarang mereka untuk mengikuti tarekat atau mendalami ajaran sufistik. Meskipun ini tidak berarti bahwa 
Anre Gurutta As'ad tidak mempraktekkan ajaran sufi. Beliau sediri pernah berguru dan menjadi sekretaris pribadi pada seorang ulama besar Madinah, pemimpin Tarekat Sanusiyah bernama Syekh Ahmad al-Syarif, pada tahun 1928 sebelum hijrah ke Sengkang. Menurut Martin van Bruinessen, dari sini bisa ditemukan jejak-jejak tarekat Sanusiyah di Sulawesi Selatan. ${ }^{17}$

Terdapat beberapa alasan yang bisa menjelaskan mengapa tradisi sufistik terlebih lagi tradisi tarekat, khususnya pada jaringan pesantren murid Anre Gurutta As'ad, tidak begitu mengakar dalam kultur pesantren Bugis-Makassar. Pertama, Anre Gurutta As'ad sebagai guru utama kebanyakan ulama Sulawesi Selatan awal abad 20, tidak mengajarkan secara formal suatu tarekat tertentu. Meskipun dalam pengajian halaqah yang dibinanya menggunakan kitab “Tanwīr al-Qulūb" yang beraliran "Naqsyabandiyah", bahkan mungkin Anre Gurutta As'ad telah diinisiasi (dibaiat) oleh beberapa aliran tarekat seperti Naqsyabandiyah dan Syadziliyah. Kedua, untuk menghindari "kesalahpahaman" komunitas Bugis-Makassar yang pada waktu itu masih melakukan praktek-praktek sufistik (tarekat) yang keluar dari ajaran Islam. Selain itu, salah satu yang mendorong kembalinya Anre Gurutta As'ad ke Sengkang yaitu berkembangnya kepercayaan "toriolo" (nenek moyang) serta menjamurnya praktek tarekat yang tidak berdasar pada syariat. Ketiga, lebih penting lagi, Anre Gurutta As'ad lebih terfokus pada pengembangan pendidikan pesantren (relasi intelektual) dengan fokus utama pada pengembangan ilmu-ilmu klasik.

Sebagian murid Anre Gurutta ${ }^{18}$ As'ad melakukan sintesa dan menerapkan corak tersendiri dalam perkembangan pesantrennya. Anre Gurutta Ambo Dalle, misalnya, secara terang-terangan mengajarkan paham sufistik ketika mengembangkan pesantren barunya "Darul Da'wah wal Irsyad" disingkat DDI. Hal ini selain karena kecendrungan pribadinya pada "ajaran-ajaran tarekat" juga mungkin karena pertimbangan strategi pengembangan pesantren dan kondisi masyarakat yang membutuhkan pencerahan spiritual. Akan tetapi, sekali lagi pesantren DDI baik secara institusi maupun komunitas kiai-santri tidak secara resmi menganut tarekat tertentu. Lebih dari itu, para kiai juga tidak secara resmi sebagai penganut aliran tarekat tertentu. ${ }^{19}$

Medium yang tidak kalah pentingnya yang membentuk jaringan kiaipesantren abad 20 adalah penggunaan bahasa Bugis sebagai lingua franca "bahasa nasional" pesantren Bugis-Makassar. Bahasa Bugis yang juga dikenal sebagai "hurufu sulafa eppa" bahkan menjadi bahasa resmi di samping bahasa Indonesia untuk menerjemahkan teks kitab kuning (kitab klasik). Struktur kalimat dalam bahasa Bugis mirip dengan bahasa Arab 
yang lebih bercorak "jumlah fi'liyah", yaitu, kalimat yang dimulai dengan kata kerja. ${ }^{20}$

Hampir bisa dipastikan bahwa selain pesantren berbasis BugisMakassar yang secara kebetulan punya hubungan emosional dan intelektual dengan As'adiyah Sengkang, semisal, DDI, Yastrib, al-Furqan, alUrawtul Wutsqa, Ma'had 77, tidak ada lagi pesantren yang secara intensif menggunakan bahasa Bugis sebagai bahasa pengantar "penerjemah" dalam menjelaskan teks kitab kuning. Mungkin sekali kondisi ini disebabkan oleh semakin beragamnya etnisitas primordial santri seperti Bugis, Makassar, Mandar, NTB, Kalimantan, Flores, Timor Timur dan sebagainya. Padahal justru dari sinilah bisa terjadi "pertemuan budaya" atau pertukaran budaya (cultural exchange). Modalitas pesantren dalam bentuk santri multi ras sangat memungkinkan memulai preseden baik tentang pendidikan multikultralisme, seperti pendidikan multi-kulturalisme ala Charles Taylor, ${ }^{21}$ yang tertuang dalam "the politics of recognition" yang salah satu unsurnya adalah pengakuan identitas, meskipun identitas itu sendiri problematik.

Dalam konteks ini, telah terjadi apa yang disebut komunikasi lintas budaya (cross culture communication). Betapa tidak, santri Pesantren As'adiyah berasal dari pengguna bahasa yang berbeda seperti bahasa Makassar, Luwu, sedikit Mandar dan bahasa Bugis itu sendiri. Menariknya, santri yang berasal dari etnis Makassar dengan cepat bisa berinteraksi dan berbahasa Bugis dengan fasih. Jadi, setidaknya terjadi dialog budaya di antara para santri, meskipun demikian kadang-kadang juga terjadi konflik etnis antar santri.

\section{JARINGAN TEOLOGIS}

Jaringan ini terbentuk melalui adanya paham teologi yang diyakini dan dianut oleh para anre gurutta dan sejumlah buku ajar yang mereka gunakan di pesantren. Para anre gurutta meyakini dan mengamalkan teologi Asy‘ariyah dan Maturidiyyah atau ajaran Ahl al-Sunnah wa alJamāah.

Dari penelusuran terhadap banyak kiai pesantren, terlihat bahwa paham teologi mereka dapat dipolarisasikan menjadi dua: tradisional dan rasional. Corak pertama (tradisional) sangat dominan, terutama di kalangan anre gurutta di pesantren yang bernuansa NU. Sedangkan corak kedua (rasional) relatif "pinggiran" atau berada di perkotaan. Mereka yang berpaham teologi ini sebagian besar bersentuhan dan mengapresiasi pemikiran pembaruan Muhammadiyah, meskipun paham teologi Muhammadiyah cenderung kepada Asy‘ariyyah. Bentuk jaringan itu dapat pula terli- 
hat pada penggunaan buku-buku teks ilmu kalam (tauhid) di pesantren. Misalnya Umm al-Barāhin, Syarkawī, Kifāyat al-Awām, 'Aqīdat al-Awām.

\section{Jaringan Anre Gurutta H. M. As'ad dengan Ulama Abad 20 yang Berpusat di Makkah-Madinah}

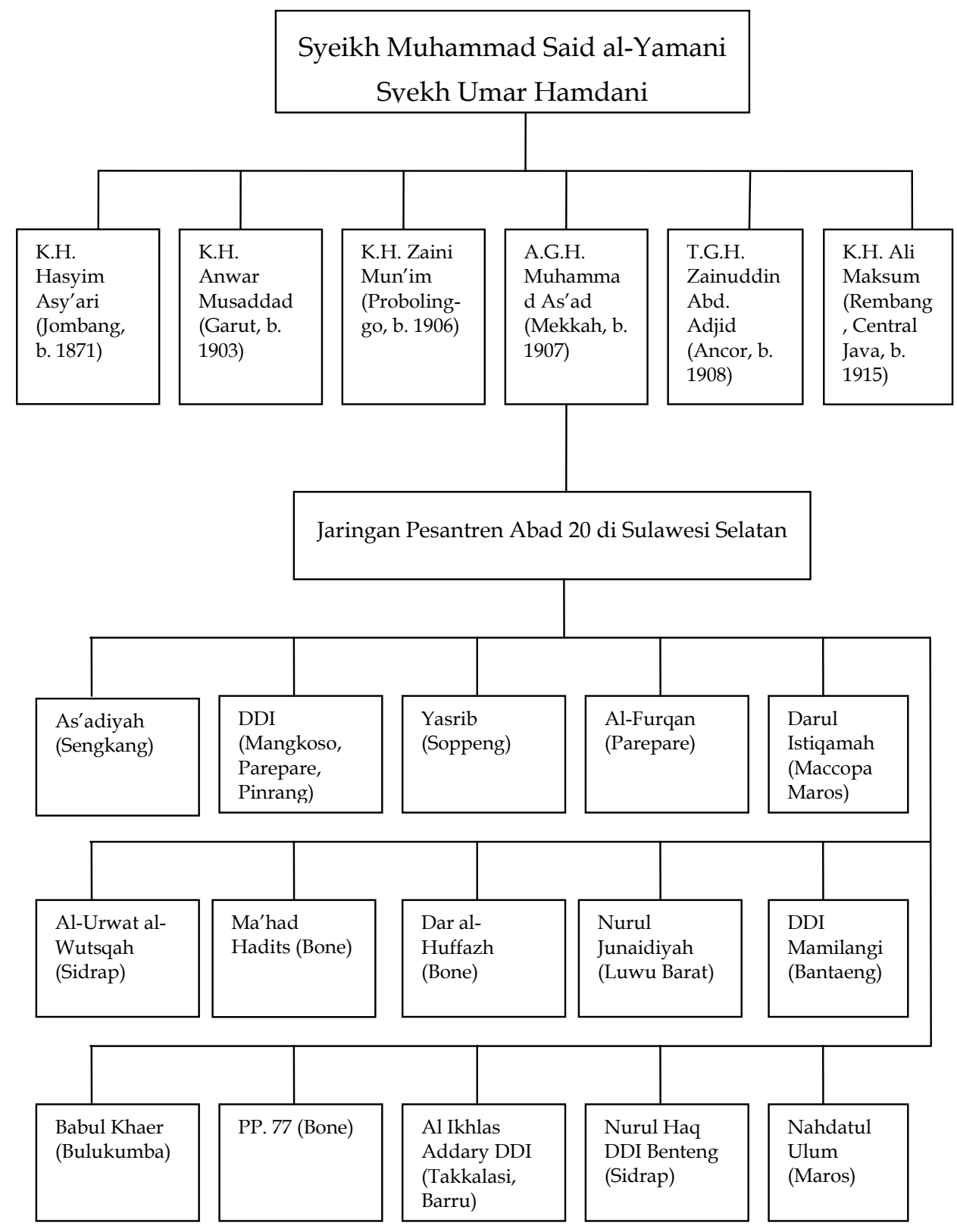


Jaringan Vertikal A.G.H. Muhammad As'ad (1907-1952)

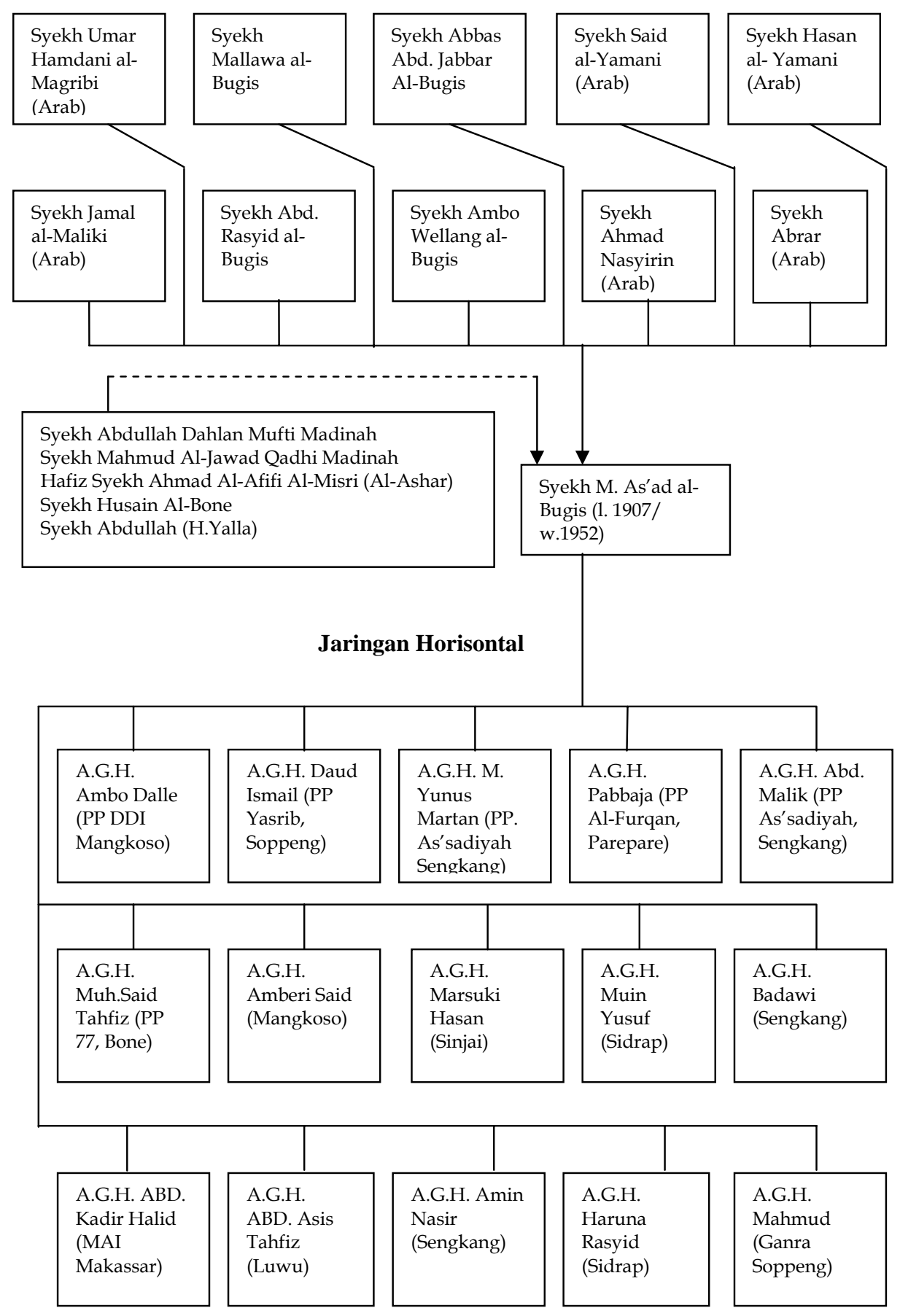




\section{PENUTUP}

Proses terbentuknya jaringan pesantren di Sulawesi Selatan abad 20 terjadi melalui relasi intelektual dan relasi horizontal sesama guru dan murid. Selain itu terjadi pula melalui pengembaraan dan link ilmu klasik seperti: fikih, hadis, Alquran, tauhid, kalam, mantiq serta ilmu bahasa Arab, sebagai yang terdapat dalam kitab kuning serta melalui transmisi ajaran sufistik (tasawuf). Adapun jaringan genealogis kiai pesantren di Sulawesi Selatan tidak begitu tampak. Tidak seperti dalam kultur pesantren Jawa-Madura, hubungan kekerabatan sesama kiai tidaklah menjadi mainstream yang membentuk poros jaringan pesantren di Sulawesi Selatan. Hal ini dimungkinkan karena hampir semua pesantren di Sulawesi Selatan dibangun dan dibentuk oleh masyarakat muslim bersama-sama dengan penguasa setempat. Dalam kaitan ini dapat pula disimpulkan bahwa dinamika jaringan pesantren tersebut terbentuk melalui jaringan vertikal dan horisontal, perdagangan, pengembaraan, dan pencarian ilmu.

\section{CATATAN AKHIR:}

1. Said Aqiel Siraj, "Membangun Tradisionalitas Pesantren untuk Kemajuan", dalam Saifullah Ma'sum (ed.), Dinamika Pesantren (Telaah Kritis Keberadaan Pesantren Saat ini), cet. I, Jakarta: Yayasan Islam al-Hamidiyyah dan Yayasan Saifuddin Zuhri, 1998, h. 23.

2. A. Wahid Zaini, Dunia Pemikiran Kaum Santri, Yogyakarta: LKPSM, 1995, h. 93.

3. Suwito dan Muhbib, "Jaringan Intelektual Kiai Pesantren di Jawa dan Madura Abad XX", Laporan Hasil Penelitian Kompetitif, Jakarta: Departemen Agama R.I., 2000, h. 69.

4. Perintis dan pengasuh mata kuliah ini adalah Azyumardi Azra. Tujuan utama mata kuliah ini adalah memberikan pemahaman baru tentang Sejarah Islam di Indonesia, sejak awal kehadiran Islam di wilayah ini sampai masa kontemporer. Meskipun pembahasan berpusat pada Indonesia, tetapi wilayahwilayah lain di Asia Tenggara juga disinggung. Pembaruan mencakup seluruh aspek perkembangan historis dan pembentukkan tradisi Islam di Indonesia sambil melihat keterkaitannya dengan perkembangan Islam pada tingkat dunia Islam. Lihat Azyumardi Azra, Pendidikan Islam: Tradisi dan Modernisasi Menuju Milenium Baru, cet. I, Jakarta: Logos, 1999, h. 270.

5. Zamakhsyari Dhofier, Tradisi Pesantren: Studi Tentang Pandangan Hidup Kyai, cet. IV, Jakarta: LP3ES, 1985, h. 21.

6. Suwito dan Muhbib, "Jaringan Intelektual Kiai Pesantren di Jawa dan Madura Abad XX", Laporan Hasil Penelitian Kompetitif, Jakarta: Direktorat Pembinaan Perguruan Tinggi Agama Islam, 2000, h. 54.

7. Hadis ini antara lain diriwayatkan oleh Abu Daud dalam Sunan-nya.

8. Suwito dan Muhbib, "Jaringan Intelektual Kiai Pesantren di Jawa dan Madura Abad XX", Laporan Hasil Penelitian Kompetitif, h. 54.

9. Masdar F. Mas'udi, "Pandangan Hidup Ulama di Indonesia dalam Literatur 
Kitab Kuning", Makalah, disajikan pada seminar nasional tentang Pandangan dan Sikap Hidup Ulama Indonesia, Jakarta: LIPI, 24-25 Februari 1988, h. 21. Lihat pula Suwito dan Muhbib, "Jaringan Intelektual Kiai Pesantren di Jawa dan Madura Abad XX", Laporan Hasil Penelitian Kompetitif, h. 4.

10. Afandi Mochtar, "Tradisi Kitab Kuning: Sebuah Observasi Umum", dalam Marzuki Wahid, dkk (ed), Pesantren Masa Depan: Wacana Pemberdayaan dan Transformasi Pesantren, Bandung: Pustaka Hidayah, 1999, h. 233-234.

11. Dalam kaitan ini Brunessen berpendapat bahwa secara keseluruhan terdapat kesamaan mencolok antara kurikulum di pesantren-pesantren di Indonesia dan di Madrasah Kurdi. Hal ini disebabkan oleh orang-orang Kurdi dan Indonesia (tradisional) sama-sama mengikuti mazhab Syafi' $i$, bisa diduga adanya kesamaan tertentu, dan perbedaan yang besar dengan kurikulum di daerah-daerah yang mengikuti mazhab lain (misalnya kurikulum fikih di India dan Kerajaan Usmani, yang di situ mazhab Hanafi dominan). Kesamaan dimaksud dapat dicontohkan dari buku fikih yang mulai dipakai oleh para pelajar, yakni kitab Takrib, kemudian Fath al-Qarib yang disudahi dengan Hasyiyah Bajuri. Lihat Martin van Bruinessen, “... Bukankah orang Kurdi yang mengislamkan Indonesia", dalam Pesantren No. 4 Tahun 1, 1987, h. 43-53. Lihat pula Bruinessen, Kitab Kuning, h. 129-130.

12. Informasi umum Pondok Pesantren Darud Da'wah wal Irsyad Abdurrahman Ambo Dalle (DDI-AD) Mangkoso Sulawesi Selatan (Brosur, t.t.), h. 3-4.

13. Suwito dan Muhbib, "Jaringan Intelektual Kiai Pesantren di Jawa dan Madura Abad XX", Laporan Hasil Penelitian Kompetitif, h. 73.

14. Gurutta adalah istilah lokal (Bugis) yang merupakan gelar non-formal oleh masyarakat Muslim setempat kepada seseorang yang mempunyai ilmu agama yang tinggi. "Guru" itu sendiri berarti guru atau orang yang mengajar, sedangkan kata "ta" pada "gurutta" berfungsi sebagai "kepemilikan" yang kemudian diartikan "guru kita". Ada juga istilah lain untuk menyebut seorang ahli dalam ilmu agama, yaitu "to panrita" yang artinya orang berilmu.

15. Tholhah Hasan, "Prolog: Hibrida Kultural dan Tradisi Intelektual Pesantren dari Masa ke Masa", dalam Mastuki HS dan M. Ishom el-Shafa (ed.), Intelektualisme Pesantren: Potret Tokoh dan Cakrawala Pemikiran di Era Pertumbuhan Pesantren, Jakarta: Diva Pustaka, 2004, h. vii.

16. Tidak bisa dipungkiri bahwa keberadaan jaringan intelektual pesantren bisa menjadi referensi untuk menentukan tingkat penerimaan dan pengakuan masyarakat terhadap seorang "gurutta" atau "kiai". Jadi, bukan hanya memberlakukan prinsip otentisitas melainkan juga prinsip orisinalitas secara bersamaan.

17. Martin van Bruinessen, Kitab Kuning Pesantren dan Tarekat: Tradisi-tradisi Islam di Indonesia, Bandung: Mizan, 1995, h. 201-201.

18. Anre Gurutta Muhammad Hasan (Majelis Pendidikan Tinggi PB As'adiyah Sengkang), Wawancara, Sengkang, 5 Januari 2006 dan Anre Gurutta Abdul Pabaja, Wawancara, Pare-Pare, 20 Januari 2006.

19. Irfan Hasanuddin, Dosen STAIN Palopo, Wawancara, Jakarta, 2 Maret 2007.

20. Andi Faisal Bakti, Dosen UIN Syarif Hidayatullah Jakarta, Wawancara, 7 Maret 2007.

21. Charles Taylor et all, Multiculturalism: Examining the Politics of Recognition, New Jersy: Princeton University Press, h. 35. 


\section{DAFTAR PUSTAKA:}

Azra, Azyumardi, Jaringan Ulama Timur Tengah dan Kepulauan Nusantara Abad XVII dan XVII, Bandung: Mizan, 1994.

------, Pendidikan Islam: Tradisi dan Modernisasi Menuju Milenium Baru, cet. I, Jakarta: Logos, 1999.

Bruinessen, Martin Van, “... Bukankah Orang Kurdi yang Mengislamkan Indonesia", dalam Pesantren No. 4 Tahun 1, 1987.

-------, Kitab Kuning Pesantren dan Tarekat: Tradisi-tradisi Islam di Indonesia, Bandung: Mizan, 1995.

Departemen Agama Republik Indonesia, Alquran dan Terjemahnya, Semarang: CV Toha Putra 1989.

Dhofier, Zamakhsyari, Tradisi Pesantren: Studi Tentang Pandangan Hidup Kyai, cet. IV, Jakarta: LP3ES, 1985.

Hasan, Tholhah, "Prolog: Hibrida Kultural dan Tradisi Intelektual Pesantren dari Masa ke Masa", dalam Mastuki HS dan M. Ishom el-Shafa (ed.), Intelektualisme Pesantren: Potret Tokoh dan Cakrawala Pemikiran di Era Pertumbuhan Pesantren, Jakarta: Diva Pustaka, 2004.

Informasi Umum Pondok Pesantren Darud Da'wah wal Irsyad Abdurrahman Ambo Dalle (DDI-AD) Mangkoso Sulawesi Selatan (Brosur, t.t.).

Mas'udi, Masdar F., "Pandangan Hidup Ulama di Indonesia dalam Literatur Kitab Kuning", Makalah, disajikan pada seminar nasional tentang Pandangan dan Sikap Hidup Ulama Indonesia, Jakarta: LIPI, 24-25 Februari 1988.

Mochtar, Afandi, "Tradisi Kitab Kuning: Sebuah Observasi Umum", dalam Marzuki Wahid, dkk. (ed.), Pesantren Masa Depan: Wacana Pemberdayaan dan Transformasi Pesantren, Bandung: Pustaka Hidayah, 1999.

Siraj, Said Aqiel, "Membangun Tradisionalitas Pesantren untuk Kemajuan", dalam Saifullah Ma'sum (ed.), Dinamika Pesantren (Telaah Kritis Keberadaan Pesantren Saat ini), cet. I, Jakarta: Yayasan Islam al-Hamidiyyah dan Yayasan Saifuddin Zuhri, 1998.

Suwito dan Muhbib, "Jaringan Intelektual Kiai Pesantren di Jawa dan Madura Abad XX", Laporan Hasil Penelitian Kompetitif, Jakarta: Depag R.I., 2000.

Taylor, Charles, et all., Multiculturalism: Examining the Politics of Recognition, New Jersey: Princeton University Press, 1994.

Zaini, A. Wahid, Dunia Pemikiran Kaum Santri, Yogyakarta: LKPSM, 1995. 